\title{
Listy w sprawach osobistych na lamach prasy
}

Małgorzata Szpakowska 
nAPOS Seria IX $2(x) 3$

\section{Małgorzata Szpakowska}

\section{Listy w sprawach osobistych na łamach prasy}

$\mathrm{P}$ sałam książkę o polskiej samowiedzy obyczajowej. Posłıgiwałam się w tym celı różnymi rodzajami publikowanych (takie bylo zatożenie) wypowiedzi spontanicznych i pól-spontanicznyclı. Takich, jak przeznaczone do druku pamiętniki, również konkursowe. I takich również, jak listy do redakcji czasopism, przede wszystkim kobiecych.

Czym są panıętniki - wiemy: są to niewątpliwie dokumenty autobiograficzne, czy, jak to nazywal Florian Znaniecki, ,dokumenty ludzkie”. Można wobec nich posłıgiwać się kategorią paktu autobiograficznego i klasyfikować je wedhug zasad zaproponowanych przez Małgorzatę Czermińską jako pozostające w trójkącie: świadectwo - wyznanie - wyzwanie. Czy jednak dokumentani autobiograficznymi są również listy do gazet, odwołujące się do osobistych doświadczeń autorów?

Moim zdaniem tak, choć są to w ogóle teksty osobliwe i trochę poza istniejącymi klasyfikacjami. Na przykład mój ulubiony list do redakcji „Kobiety i Życia” zaczyna się od słów: „Moja córka jest dziwką”. W innym czytamy: „Ile bym dała dwadzieścia lat temu, aby ojciec moich dzieci odwiedzil je czasem, porozmawiał z nimi albo kupił im jakąś zabawkę". Korespondentka „Wysokich Obcasów” opowiada: „Nieraz myślę, że niedlıgo chyba cała fizjologia zostanie zlikwidowana. (...) Być może za kilka lat zakazane będzie nawet bycie starym". Inna zwierza się: ,jesteśmy [z mężem] niemodni, nierozsądıi, niezrozımiani i... bezwstydnie szczęśliwi”. Jeszcze imna pisze: „Po rozpadzie mojego małżeństwa (...) kilka lat byłam sama i stanowiło to dla mnie prawdziwą torturę." Jak można zaszeregować takie teksty?

Z pozoru wydaje się, że i tu pasują wyznaczniki genologiczne wskazane przez Stefanię Skwarczyńską w Teorii listu. Cytowane teksty są - w myśl jej kryteriów - utylitarne (bo napisane zostaly w jakiejś sprawie); sporządzone w formie pisemnej (nawet jeśli przekazano je elektronicznie); powstałe pod nieobecność adresata (zastępują kontakt twarzą w twarz); i wreszcie adresat jest biernym, ale jednak współautorem otrzymywanej korespondencji (po- 
nieważ ma wplyw na jej ksztalt) ${ }^{\prime}$. Widać jednak od razu, że nie wyczerpuje to problemu: w listach do redakcji adresat - zbiorowy i niewiadomy - ma przeciez zupełnie nowy charakter. Przypominam: adresatami listów, o których tu mowa, nie są redaktorzy, możliwa do ustalenia grupa osób; taki list kierowany jest do ogólu czytelników, którym prezentujemy problem wręcz intymny. Powstaje osobliwa sytuacja komunikacyjna: intymność formy (list) i treści (doświadczenie osobiste) pozostaje w sprzeczności z adresatem, który jest publiczny i anoninowy.

Podobnie niewystarczające wobec takich listów okazują się kryteria zaproponowane przez Jana Trzynadlowskiego - , .list w swej istocie jest przede wszystkim manifestacją nadającego podmiotı” i jako wieloaspektowy fakt językowy obok informacji zawiera „skladniki kontaktywności z odbiorca"-2. Co do manifestacji podmiotu - zgoda; z kontaktem natomiast jest gorzej. Warto jednak podkreślić, że Trzynadlowski zwraca uwagę również na ponadindywidualną zawartość ,wypowiedzi osobistych” i ich przydatność nie tylko dla adresata, lecz również na przyklad dla historyka czy socjologa:

...list zazwyczaj niezależnie od intencji nadawcy prócz informacji będących dlań czynnikiem sprawczym (przyczyny powstania) zawiera dane dodatkowe, nieraz w wysokim stopniu charakteryzujące i nadawcę, i odbiorcę.

Ale Trzynadlowskiemu chodzi o uboczny niejako użytek, jaki badacz może uczynić z listu, podczas gdy w przypadku listów intymuych do prasy jest to ich sens i cel podstawowy.

W przypadku listów osobistych do prasy nieadekwatna jest także kategoria „listu otwartego". Listy takie piszą zazwyczaj osoby powszechnie znane w sprawach dotyczących ogólu. Jest to więc raczej odmiana publicystyki, którą z epistolografią lączy tylko nazwa. Tymozasem nasze listy pochodzą od osób nieznanych i często anonimowych; dotyczą zaś ich spraw często bardzo prywatnych. Upublicznieniu podlega tu osobisty komunikat pochodzący od anonimowego autora: gazeta staje się rodzajem konfesjonału, tyle że wyposażonego w nagłośnienie. Daleko stąd do klasycznych listów do ..Timesa”, w których oburzeni czytelnicy informowali, że konie w stajni X. traktowane są niewłaściwic albo że pan Disracli postąpił haniebnie. Blizej natomiast zdecydowanie do konkursowych dzienników i pamiętników, też z założenia przenoszących sprawy prywatne na forum publiczne. Czyli właśnie do dokumentów autobiograficznych.

Wykorzystywanie materiałów autobiograficznych ma w polskiej praktyce badawczej długą tradycję. Zapoczątkowal jă, jak wiadomo, Znaniecki, kontynuowali Józef Chałasiński, Jan Szczepański, Witold Kula. Założenia metody autobiograficznej Znanieckiego sformułowane zostały w związku z pracą o Chtopic polskim u' Europie i. Ameryce, i jest to oczywiście tekst najbardziej klasyczny. Warto jednak zw rócić uwagę także na inną jego niewielką książkę z 1931 roku, Miasto u'śn'iadomości jego oby'u'ateli. Praca ta, na podstawie zaledwie dwudziestu siedmiu ankiet,

'Por. S. Skwarczyniska. Tevria listu. Lwów 1437. s. 37-38.

2 J. Trzynadlowski, Mate formy literakie. Wroclaw 1977. s. 76 i 77; kolcjny cytat - s. 86. 
rekonstruowała, że pozwolę sobie tak to nazwać - samowiedzę obywatelską mieszkańców Poznania.

"Wypowiedzenia ludzkie”, pisze tam Znaniecki, można traktować w dwojaki sposób. Po pierwsze, jako wyraz obserwacji i uogólnień społecznych wypowiadającego, po drugie zaś, jako świadectwo jego dążności i ocen. Prawdziwość wypowiedzi interesuje nas tylko w pierwszym przypadku; w drugim wypowiedzenia

...nie mają charakteru prawd o faktach, lecz same są faktami społecznymi. Nie wyrazają one bowiem obserwacji, lecz aktywne, normatywne, regulatywne lub rozwojowe dążenia wypowiadającego: dążność do wykonania pewnego czynu, poczucie pewnego obowiązku, chęć narzucenia pewnej normy postępowania imnym ludziom, pragnienie realizacji pewnego ideahı grupowego ${ }^{3}$.

Jeśli więc - kontynuıje Znaniecki - ktoś krytykuje księży poznańskich za to, że zbyt mało interesują się parafianami, to być może mówi nieprawdę; niewątpliwie jednak wyraża opinię, że księża powimni zajmować się mieszkańcami parafii - i sam fakt, że wyraził taką opinię, już nie ulega wątpliwości. Jeśli zaś ktoś inny uważa język mieszkańców Poznania za zachwaszczony niemczyzną, to sformulowanie tego rodzaju zarzutu zawiera implicite przekonanie, że człowiek obowiązany jest dbać o czystość języka ojczystego, i tak dalej.

Wypowiedzi takie, nawet gdy do tego wprost nie pretendıją, mają zwykle pewien wymiar ponadindywidualny:

Przeciętny osobnik ludzki bowiem przyjmuje ze swego środowiska tylko takie dążenia, które są w tym środowisku rzéczywiście aktualıe.

Jeśli zaś jakiś pogląd powtarza się kilkakrotnie, wolno sądzić, że

...nie stanowi idiosynkrazji takiego czy innego autora, lecz jest wyrazem normy lub idealu, refleksyjuie lub bezrefleksyjnie uznawanego przez wielu obywatcli.

Innymi słowy, zdaniem Znanieckiego, mówimy nie tylko we wlasnym imieniu, lecz także w imieniu tych, którzy nas tak czy inaczej współukształtowali. Nasze wypowiedzi ujawniaja bowiem system norm, jakie — świadomie lıb nie - wyznajemy; normy zaś z natury rzeczy mają charakter ponadindywidualny.

Znaniecki pisat o „dokumentach ludzkich”, Chalasinski o „wypowiedziach autobiograficznych”, Szczepański zaśo „dokumentach osobistych” lub „autobiograficzuych”. Jednak co do ich wartości jako źródla w badaniach społecznych wszyscy mieli pogląd podobny. Chatasiński wprost podkreślał wymiar ponadindywidualny takich materiałów i prawomocność czynionych na tej podstawie uogólnień: 
Grupy spoleczne nie istnieją poza jednostkami, lecz tylko w doświadczeniu składających je jednostek ${ }^{+}$.

Podobnic o prawomocności wykorzystywania takich dokumentów wypowiadał się Szczepański. ${ }^{5}$ Obaj też zwracali uwagę, że kłamstwo i przemilczenie bywają równie interesujące jak prawda i szczerość; obaj wreszcie przedstawili pewnego rodzaju klasyfikację badanych źródel. Chałasiński pisał o dwóch biegunach, międ zy którymi rozciąga się continunun dokumentów osobistych: na jednym z nich sytuıje siç zobiektywizowana kronika, usuwająca w cień osobę narratora; na drugim — intymne wyznanie osobiste (jak świętego Augustyna albo Jana Jakuba Rousseau1). Klasyfikacja Szczepanískiego jest bardziej przyziemna i odwołuje się do doświadczenia. jakie wynika z organizowania konkursów tematycznych. Materiały uzyskiwane w takich konkursach można podzielić na cztery kategorie: kroniki, samousprawiedliwienia, wyznania i autoanalizy. Dla badacza najbardziej przydatna jest krzyżówka kroniki i wyznania; należy więc tak formułować warunki zamówienia, by zminimalizować liczbę odmian niepożądanych. Nie ma powodu, by tych wszystkich ustaleń nie stosować wobec listów osobistych kierowanych do gazet. Ale tu znowu pojawiają się ograniczenia.

Wiemy juz, że do listów tego rodzaju nie pasują ustalenia badaczy, którzy - jak Skwarczyńska czy Trzynadlowski - zajmowali się epistolografią od strony teoretycznoliterackiej; przedmiotem ich zainteresowania byly przewaznie listy kicrowane do indywidualnych adresatów, i to kierowane przez wybitnych autorów — od Seneki po Zygmunta Krasińskiego. Ale téz- z drugiej strony - nie do koníca stosują się tu uwagi Witolda Kuli, który podał do druku skonfiskowane przez carską cenzurę listy dziewiętnastowiecznych emigrantów do Brazylii i Stanów Zjednoczonych. Były to listy w zasadzie prywatne, choć przeważająca ich część jako że kierowali je analfabeci do analfabetów - pisana byla i potem odczytywana przez pośredników. Co więcej. pojedynczy skryba obsługiwał często całą grupę nadawców jednocześnie, a pojedynczy lektor - calą grupę odbiorców; co świadczyć mogło — pisze Kula -

...o odczuwaniu listu nie jako środka intymnego porozumicnia autora z adresatem, lecz jako kontaktu międ zy zbiorowościami, czy międ zy zasadniczą zbiorowością, tą w kraju, a jej odgalęzieniem za oceanem".

Ale i w takiej sytuacji adresat listu — choć zbiorowy — był jednakjakoś znajomy nadawcy. Inaczej niż w przypadku listów napływających do „Kobiety i Życia” i do „Wysokich Obcasów", a także do innych pism kobiecych, którymi zajmowalam się tylko sporadycznie. Również z powodu ich odmienności gatunkowej. Listy publikowane w „Claudii”, „Zwierciadle” czy „Twoim Stylı” zawierały bowiem najczęściej albo wyrazy uznania dla redakcji (za cało-

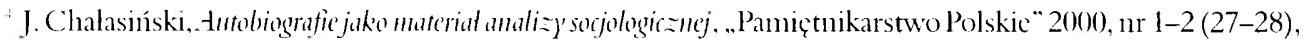
s. 24.

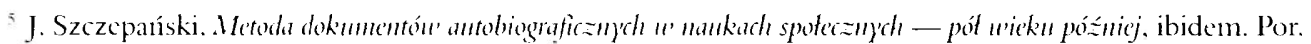
także artykul z 1967 roku. Metoda biograficzna, w: idem, Odmiany calsu terazmiejszego, Warszawa 1973.

"Listy e'migrantóu' = Brazylii i Stanón' Zjednoczonych 1890-1891. opr. W. Kula. N. Assorodobraj-Kula, M. Kula, Warszawa 1973, s. 32. 
ksztalt lub poszczególne artykuły) albo też prośby o konkretne porady (jak pozbyć się łupieżu?, jak upiec pieruik?, gdzie szukać najlepszego szpitala położuiczego?). W pierwszym przypadku adresat był zatem wyraźnie określony — byl nim po prostu zespól redakcyjny. W przypadku drugim — prośby o poradę — temat można uznać za ponad osobisty — w końcu przepis na piernik mógł się przydać każdemu z czytelıików. W obu wariantach warunek ujawnienia spraw osobistych wobec anonimowego adresata nie został spetniony.

Natomiast analizowane przeze mnie listy do „Kobicty i Życia” i "Wysokich Obcasów” ten warunek z pewnością spelniały. Czy to znaczy, że można je uznać za świadectwo wiarygodne? Tego oczywiście nie da się orzec. Wydaje się natomiast, że również do tej odmiany dokumentów osobistych z pożytkiem można zastosować wypracowaną przez Philippe’a Lejeune'a kategorię paktu autobiograficznego. Zdaniem Lejeune’a, jak wiadomo, materiały autobiograficzne są tekstami referencjalnymi w tym sensie, że nie chodzi w nich (inaczej niż w literaturze pięknej) o wykreowanie rzeczywistości fikcyjnej, lecz o przedstawienie jej obrazu; z kolei od wypowiedzi naukowych czy dziennikarskich różnią się tym, że ich weryfikacja jest niemożliwa. Więcej nawet, jak pisze Lejeune:

W autobiografii jest wprawdzie niezbędne, by pakt referencjalny został zawarty i dotrzymany, lecz rezultat nie wymaga oceny w kategoriach ścislego podobicístwa ${ }^{7}$.

W odniesieniu do naszych materiałów pakt autobiograficzny oznacza muniej więcej tyle samo, co cytowana wcześniej opinia Znanieckiego o drugorzędnym znaczeniu prawdziwości „dokumentów ludzkich”: jeśli ktoś opowiada o czymś, co mu się zdarzylo, i czyni to w pierwszej osobie, a w dodatku poświadcza swoje słowa „podpisem autobiograficznym” (choćby pozostawionym tylko do wiadomości redakcji), to wypowiedź taka spelnia wszystkie kryteria formalne. Może być traktowana jako autobiograficzna, nawet gdy jest zdecydowanie nieścisha.

Oczywiście, inaczej ocenia się spowiedź z całego życia, a inaczej krótki list do prasy; obu jednak, z mocy tego samego paktu, przysługıje domniemanie autentyzmu. Nie tylko dlatego, że, jak powiada Lejeune gdzie indziej, pełnej prawdy o sobie i tak nikt nie jest w stanie przedstawić ("Powiedzieć prawdę o sobie, ustanowić się jako podmiot pelny - to urojenie”, a jednak „To, że autobiografia nie jest możliwa, wcale nie przeszkadza jej istnieć”). Równicż dlatego, że tak po prostu dyktuje zdrowy rozsądek. Sam pakt autobiograficzny, który zawieram $z$ autorem dokumentu osobistego, zaklada formalną szczerość z jego strony i równie formalne zaufanie z mojej. Inaczej nie mielibyśny nad czym się zastanawiać.

Listy osobiste do czasopism dają się również opisywać w proponowanych przez Małgorzatę Czerminíską kategoriach „świadectwa, wyznania i wyzwania”. Te trzy wymiary, składa-

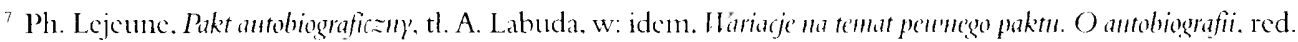
R. Lubas-Bartoszyniska. Kraków 20()1, s. +7: kolejny cytat z artykulu Pakt antobiografiz:m) (bis), tl. S. Jaworski. w: ibidem, s. 197. 
jące się na „autobiograficzny trójkąt”, za każdym razem pozwalają opisać rodzaj (czy raczej przewagę) postawy ,ja" mówiącego. Postawa świadka koncentruje się na opisie świata zewnętrznego, postawa autora wyznania - na ,ja" lirycznym czy narcystycznym; wyzwanie wreszcie nakierowane jest na odbiorcę, którego przyzwyczajenia i poglądy próbuje naruszyć.

Każdy autobiograficzny zapis — kontynuuje autorka — sytuuje się gdzieś między tymi abstrakcyjnymi biegunami. W materii konkretnego tekstu możemy mówić tylko o dominacji jednego bieguna nad innymi, ale nigdy o wykluczeniu któregośs.

Godzi się zauważyć, że zależnie od przewagi jednej z tych postaw kwestia referencyjności tekstu będzie miala większe lub wręcz minimalne znaczenie: prawdziwość, istotna w świadectwach, jest niemożliwa do oszacowania w wyznaniach lirycznych i całkiem traci na znaczeniu w wyzwaniach. List „Moja córka jest dziwką...” jest tego oczywistym przykladem.

Jeśli listy osobiste kierowane do czasopism (a także pamiętniki pisane na konkursy) coś w ogóle wyróżnia w stosunku do reszty dokumentów osobistych, to nie postawa narratora ani poziom wiarygodności, lecz ostentacja upublicznienia. Znawcy przedmiotu - choćby oboje cytowani przed chwila - twierdzą wprawdzie, że nawet najbardziej intymny dziennik czy pamiętnik pisany jest zwykle z myślą, że go w końcu ktoś kiedyś przeczyta. Jest jednak pewna różnica między tekstem pisanym dla ewentualnego lektora z przyszłości a tekstem adresowanym do gazety codziennej. W tym ostatnim przypadku przekonanie o własnej reprezentatywności musi być chyba znacznie wyższe. Co oczywiście nie znaczy, że uzasadnione.

Wbrew pozorom, listów osobistych kierowanych do czasopism nie ukazuje się już wiele i wydaje się, że może to być gatunek zanikający. Nie tylko dlatego, ze ich funkcję w coraz większym stopniu przejmują internetowe portale dyskusyjne (aczkolwiek listy do redakcji też bywają „interaktywne”; tyle że między komunikatem a odzewem upływa często kilka tygodni). I nie tylko dlatego, że rolę publiczınego konfesjonału zagarnęła prawie w całości telewizja. Również dlatego, że w wielu pismach miejsce listów dotyczących przeżyć lub przekonań zajęly prośby o konkretne porady oraz komentarze fachowców. Coraz rzadziej też listy przytaczane są in extenso czy przynajmniej w większych fragmentach; redakcje same wykorzystują zawarty w nich materiał, zamiast pozostawiać go czytelnikom do analizy. Dwa czasopisma, które wybrałam, stanowiły pod tym względem wyjątek. Przy czym „Kobieta i Życie” w polowie lat dziewięćdziesiątych zaczęla wycofywać się z roli trybuny publicznej.

Nie wszystkie listy godne są analizy i nie wszystkie nadają się do publikacji. Występują wśród nich takie same odmiany i grożą te same niebezpieczeństwa, które Szczepański wskazywał w odniesieniu do materiałów autobiograficznych. W zasadzie tylko skrzyżowanie kro-

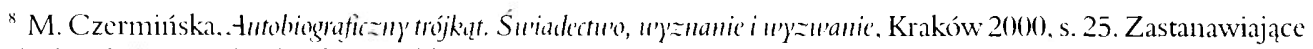
skądinąd. ze autorka, bardzo wnikliwie zajmująca siç teoretyczną problematyką dokumentów osobistych, w ogóle pomija ustalenia socjologów. w tym i te, na które siç tu powoływałam: nie ma w jej książce ani Znanieckiego, ani Chalasińskiego, ani Kuli. a autorstwo terminu .,dokument osobisty“ przypisane zostało Romanowi Zimandowi. por. op. cit.. s. 14. 
niki z wyznaniem, czyli zapisu faktów z osobistym komentarzem, stanowi dokument naprawdę wartościowy. Tymczasem spora część korespondencji redakcyjnej — nawet tej drukowanej - to w istocie kiepska publicystyka, gdzic powtarzają się powszechnie znane tezy bez żadnych nowych argumentów. Z drugiej strony zaś poważną grupę listów stanowią, równie mało osadzone w realiach, harlequinowe opowieści o uczuciach. Taki charakter mial cykl opowieści o zdradach malżeńskich Moja nieu iernoš́, który przez dłuższy czas ukizywal się w „Zwierciadle”; podobna rubryka w 1996 roku pojawila się w „Kobiecic i Życiu”. Można to potraktować jako jeszcze jeden dowód, że osobiste listy do redakcji są gatunkien wymierającym.

Szkoda, bo jest to źródlo znakomite. Choć warto paniętać, ze nieco jednostronne. Po pierwsze dlatego, że autorkani takich listów są prawie wylącznie są kobiety. 1)ecyduje o tym charakter czasopism-adresatów; no tak - ale analogicznych pism dla mężczyzn po prostu nie ma. A nie ma zapewne dlatego, że w naszej kulturze mężczyźni rzadko opowiadają o ıczıciach i obyczajach, i chyba nic odczuwają takiej potrzeby. W „Wysokich Obcasach” zamieszczono wprawdzie kiedyś list od czytelnika, który dramatycznie pytał, gdzie właściwie mężczyzna może opowiedzieć o swoim życiu osobistym; do prasy „.męskiej” zalicza się bowiem zwykle pisma motoryzacyjne i „Playboya”. Był to jednak głos odosobniony. Na ogół zaś znane mi męskie wypowiedzi, które ocieraly się o tematy obyczajowe, miały raczej charakter komentarzy politycznych i publicystycznych.

Wydaje się więc, że w piśmiennictwie nie-artystycznym potwierdzają się wnioski formulowane zwykle na podstawie beletrystyki. Przyjnuıje się, że w literaturze pięknej istnieje coś takiego, jak specyfika kobieca: domeną kobiet są uczucia i obyczaje, gdy domeną mężczyzn (z grubsza) wszystko inne. Czy rzeczywiścic? Pojęcie „écriture fémimine” obrosło rozmaitymi interpretacjami, w zasadzic jednak, cokolwiek upraszczając, można wskazać dwa jego podstawowe znaczenia. Pierwszym posługuje się I félène Cixous i zbliżone do niej badaczki francuskie; w tym znaczeniu pisarstwo kobiece jest zdeterminowane biologicznie i wyrasta bezpośrednio z doświad czania kobiecej cielesności i fizjologii". Rozumienie drugie natomiast sprowadza pytanie o „pisarstwo kobiece” po prostu na grunt konwencji literackiej; tak czynić proponuje na przykład Ewa Kraskowska ", w zasadzie uniezależniając sprawę „kobiecości” tekstów od plci autorów. W jej ujęciu literatura kobieca to literatura przezuaczona dla kobiet i odpowiednio „sformatowana” na ich uzytek: z tradycji dawnego obcowania kobiet ze sobą trwa tu koncentracja na bliźnich (relacje interpersonalne, plotki) i na sanych mówiących (zwierzenia); natomiast z warsztatowych wynalazków dwudziestego wicku wykorzystywane są autotematyzm, intertekstualność i stylizacja.

W listach do redakcji pism kobiecych niewątpliwie spełniona jest pierwsza część opisu Kraskowskiej - tematyczna. To rzeczywiście jest „écriture féminine” - tak w potocznym, jak w genologicznym znaczeniu. O zachowaniu kryteriów warsztatowych mówić trudniej, skoro

\footnotetext{
"Por. I I. Cixous, Śmiéd .Meduzy', tł. A. Nasiłowska. ,Teksty Drugic" 1993, nr 4-6.

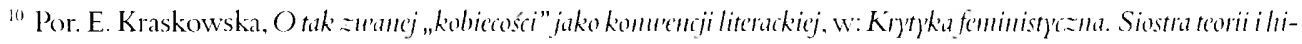
storii literatury, red. G. Burkowska, L. Sikorska. Warszawa 2000().
} 
nie są to utwory artystyczne. Choć już w pamiętnikach kobiecych podjęłabym się wskazać zarówno skłonności autotematyczne, jak gry intertekstualne. Nie wydaje się natomiast, by z omawianych tu tekstów zadowolona byla H lélène Cixous: są one bowiem zasadniczo bezcielesne. Poszczególne wypowiedzi rzadko wyrastają z egzystencjalnego doświadczenia ciala; powiedzialabym nawet, że ciało podlega w nich daleko idącej instrumentalizacji. Rozpada się na oddzielne kwestie adresowane do specjalistów: ginckologów, pediatrów, dietetyków, krawców; sprawia kłopot, więc należy je naprawić. Wyjątek od tej reguły stanowią wypowiedzi kobiet w ciąży; ale tu z kolei przeważają horrory lekarsko-szpitalne. Poza tyın zaś żadna z piszących nie utożsania się z własną biologiczną płciowością. Zresztą nie czyni tego również żaden z piszących.

Niemniej nawet bez tizjologii przewaga kobiecego widzenia świata pozostaje w listach przemożna. Obraz przy tym jest jednostronny również pod imnym względem. Mamy do czynienia z oczywistą nadreprezentacją osób wykształconych. Jest to zrozumiale — osoby niewykształcone rzadziej mają̧ odruch, by na piśmie dzielić się swymi doświadczeniami czy obawami; tym rzadziej ich teksty mogą kwalifikować się do publikacji. Nie dlatego nawet, że są rewoltujące, lecz dlatego, że najczęściej pozostają nieczytehne: nieumiejętność zrozumialego formulowania myśli obraca się przeciw piszącym. Sytuacja taka jednak znacznie ogranicza zasięg ewentualnych uogólnień.

Reasumując: listy intymne do gazet wyróżniają się z powodu specyfiki nadawców — ich autorkami są kobiety z przynajnnniej średnim wykształceniem. A przede wszystkim powodują powstanie osobliwej sytuacji komunikacyjnej, w której gatunek w zasadzie prywatny i jednostkowy shuży upublicznieniu czyichś osobistych zwierzeń. Najczęściej zresztą anonimowych czy pseudonimowanych. 